\title{
KURIKULUM IDEAL, KURIKULUM AKTUAL, DAN HASIL BELAJAR
}

\author{
Ni Nyoman Mastiningsih \\ STKIP Agama Hindu Singaraja, Singaraja, Indonesia \\ nyomanmastiningsihn@gmail.com.
}

\begin{abstract}
ABSTRAK
Kurikulum merupakan komponen yang sangat vital harus diketahui oleh seorang guru, karena kurikulum dapat berperan sebagai tuntunan utama di dalam membuat RPP yang akan dikomunikasikan di kelas pada suatu bidang studi. Kurikulum yang digunakan untuk menyusun RPP oleh guru-guru bidang studi pada suatu sekolah menengah, yang merupakan turunan dari kurikulum ideal sering dikenal dengan kurikulum aktual. Sedangkan kurikulum yang dikeluarkan oleh Depdikbud yang seharusnya dikembangkan menjadi RPP dikenal sebagai kurikulum ideal. Makin jauh kesenjangan kurikulum aktual dengan kurikulum ideal, maka program pembelajaran yang dikomunikasikan oleh guru yang bersangkutan menyebabkan hasil belajar siswa menjadi rendah, yang berefek lanjut pada kualitas sekolah yang rendah. Sebaliknya, makin sempit, bahkan tidak ada kesenjangan antara kurikulum ideal dengan kurikulum aktual, maka program pembelajaran yang dikomunikasikan oleh guru yang bersangkutan menyebabkan hasil belajar siswa menjadi tinggi, yang berefek lanjut pada kualitas sekolah yang tinggi.
\end{abstract}

Kata kunci: Kurikulum ideal, kurikulum aktual, hasil belajar, dan kualitas sekolah.

\section{PENDAHULUAN}

Dalam melaksanakan fungsinya sebagai pengajar sehari-hari di kelas, seorang guru pasti mengimplementasikan rencana pelaksanaan pembelajaran (RPP) yang sudah disusun sebelumnya dengan menggunakan berbagai metode dan model pembelajaran. Metode dan model pembelajaran apapun yang digunakan untuk menyampaikan materi pelajaran kepada siswa pasti akan berujung pada peningkatan kualitas pembelajaran. Atau dalam skup yang lebih sempit bertujuan untuk meningkatkan hasil belajar siswa. Dengan kata lain, siswa yang diajar setelah diberikan tes hasil belajar dan pekerjaannya setelah diskor memperoleh skor hasil belajar sekurang-kurangnya memenuhi kriteria ketuntasan minimal (KKM) atau memperoleh skor hasil belajar di atas KKM. Untuk mencapai hal ini, maka guru bidang studi di sekolah menengah, seperti SMP dan SMA atau yang sederajat harus mematuhi langkah-langkah yang sudah direncanakan pada RPP saat pelaksanaan RPP tersebut di kelas.

Berlandaskan Undang-Undang Republik Indonesia nomor 20 tahun 2003 tentang Sistem Pendidikan Nasional dan Peraturan Pemerintah (PP) nomor 19 tahun 2005 tentang Standar Nasional Pendidikan (SNP), Pemerintah melalui Departemen Pendidikan Nasional, berkewajiban menetapkan berbagai peraturan tentang standar penyelenggaraan pendidikan di seluruh wilayah Negara Kesatuan Republik Indonesia (NKRI). Standar nasional pendidikan yang dimaksud meliputi: (1) standar isi, (2) standar 
e-ISSN : 2656-7466, p-ISSN : 1907-9559

kompetensi lulusan, (3) standar proses, (4) standar pendidik dan tenaga kependidikan, (5) standar sarana dan prasarana, (6) standar pengelolaan, (7) standar pembiayaan, dan (8) standar penilaian pendidikan.

Salah satu dari kedelapan standar itu adalah standar isi. Standar isi memuat standar kompetensi (SK) dan kompetensi dasar (KD), yang harus dicapai siswa setelah mengikuti pembelajaran dalam jenjang dan waktu tertentu, sehingga pada gilirannya mencapai standar kompetensi lulusan (SKL). Agar peserta didik dapat mencapai SK, KD, maupun SKL secara optimal perlu didukung oleh berbagai standar lainnya dalam sebuah sistem yang utuh. Salah satu standar tersebut adalah standar proses. Standar proses pendidikan adalah standar nasional pendidikan yang berkaitan dengan pelaksanaan pembelajaran pada satu satuan pendidikan untuk mencapai standar kompetensi lulusan.

Dari pengertian standar proses pendidikan di atas, ada beberapa hal yang perlu digarisbawahi. Pertama, standar proses pendidikan adalah standar nasional pendidikan, yang berarti standar proses pendidikan yang dimaksud berlaku untuk setiap lembaga pendidikan formal pada jenjang pendidikan tertentu di mana pun lembaga pendidikan itu berada secara nasional. Dengan demikian, seluruh sekolah seharusnya melaksanakan proses pembelajaran seperti yang dirumuskan dalam standar proses pendidikan ini. Kedua, standar proses pendidikan berkaitan dengan pelaksanaan pembelajaran, yang berarti dalam standar proses pendidikan berisi tentang bagaimana seharusnya proses pembelajaran berlangsung. Dengan demikian, standar proses pendidikan dimaksud dapat dijadikan pedoman bagi guru dalam pengelolaan pembelajaran. Sering orang menghubungkan tidak meratanya kualitas pendidikan disebabkan karena kualitas proses pembelajaran yang tidak sama. Ketiga, standar proses pendidikan diarahkan untuk mencapai standar kompetensi lulusan. Dengan demikian, standar kompetensi lulusan merupakan sumber atau rujukan utama dalam menentukan standar proses pendidikan. Karena itu, sebenarnya standar proses pendidikan bisa dirumuskan dan diterapkan manakala telah tersusun standar kompetensi lulusan (Sanjaya, 2010).

Sesuai dengan penekanan yang kedua dari pengertian standar proses pendidikan, yakni standar proses pendidikan berkaitan dengan pelaksanaan pembelajaran, berarti standar proses mengisyaratkan bahwa guru diharapkan dapat mengembangkan perencanaan pembelajaran seperti rencana pelaksanaan pembelajaran (RPP), pada jenjang pendidikan dasar dan menengah. RPP adalah rencana yang menggambarkan prosedur dan manajemen pembelajaran untuk mencapai satu atau lebih kompetensi dasar yang ditetapkan dalam standar isi dan dijabarkan dalam silabus. RPP merupakan pengembangan lebih lanjut dari kurikulum, yang pengembangannya harus dilakukan secara profesional (Anwar Us dan Harmi, 2011).

RPP dikembangkan berdasarkan karakteristik dan kondisi sekolah, serta kemampuan guru dalam menjabarkan menjadi rencana pelaksanaan pembelajaran yang siap dijadikan pedoman pembentukan kompetensi peserta didik. Agar guru dapat membuat RPP yang efektif, dan berhasil guna, dituntut untuk memahami berbagai aspek yang berkaitan dengan hakikat, fungsi, dan prosedur pengembangan, serta cara mengukur efektivitas pelaksanaannya dalam pembelajaran.

Guru-guru bidang studi di sekolah menengah pada suatu kabupaten, biasanya menyusun RPP berdasarkan atas silabus yang sebetulnya merupakan turunan dari kurikulum yang dikeluarkan oleh Kementerian Pendidikan Nasional di Jakarta. Bilamana silabus yang dibuat oleh kelompok kerja guru (KKG) suatu bidang studi makin jauh dari rambu-rambu yang digariskan oleh kurikulum, maka proses pembelajaran yang 
diimplementasikan menjadi rendah kualitasnya. Jika proses pembelajaran rendah kualitasnya, maka hasil belajar siswa pada bidang studi yang bersangkutan menjadi rendah. Kalau hasil belajar siswa rendah pada bidang studi matematika misalnya, dapat dipastikan makin rendah kualitas sekolah pada bidang studi matematika. Kemungkinan besar keluhan para siswa Sekolah Menengah Atas (SMA) di Kabupaten Buleleng pada tahun 2019, yang menyatakan apa yang diajarkan di sekolah oleh guru-guru bidang studi sangat jauh berbeda dengan soal-soal yang keluar pada Ujian Akhir Nasional (UAN). Salah satu penyebabnya terletak pada kesenjangan yang cukup besar antara tuntutan kurikulum dengan RPP yang diimplementasikan oleh guru-guru bidang studi pada suatu sekolah.

Untuk mengetahui kebenaran pernyataan para siswa SMA di Kabupaten Buleleng dengan kesenjangan yang cukup besar antara kurikulum yang dikeluarkan oleh Departemen Pendidikan Nasional dengan RPP yang diimplementasikan oleh guruguru bidang studi pada suatu sekolah, perlu dilakukan kajian yang mendalam mengenai kurikulum ideal dan kurikulum aktual.

Berpijak dari kenyataan-kenyataan yang sudah dikemukakan, pada artikel ini akan dikupas mengenai hubungan antara kurikulum ideal dan kurikulum aktual dengan hasil belajar siswa pada suatu bidang studi dan sekolah tertentu.

\section{METODE}

Dalam kaitannya dengan pendidikan, Tilaar (1994) mengemukakan bahwa pendidikan nasional dewasa ini sedang dihadapkan pada empat krisis pokok, yang berkaitan dengan kuantitas, relevansi atau efisiensi eksternal, elitisme, dan manajemen. Lebih lanjut dikemukakan bahwa sedikitnya ada tujuh masalah pokok sistem pendidikan nasional, yakni: (1) menurunnya akhlak dan moral peserta didik, (2) pemerataan kesempatan belajar, (3) masih rendahnya efisiensi internal sistem pendidikan, (5) status kelembagaan, (6) manajemen pendidikan yang tidak sejalan dengan pembangunan nasional, dan (7) sumber daya yang belum profesional.

Menghadapi hal tersebut perlu dilakukan penataan terhadap sistem pendidikan secara kaffah (menyeluruh), terutama berkaitan dengan kualitas pendidikan, serta relevansinya dengan kebutuhan masyarakat dan dunia kerja. Dalam hal ini, perlu adanya perubahan sosial yang memberi arah bahwa pendidikan merupakan pendekatan dasar dalam proses perubahan itu. Pendidikan adalah kehidupan, untuk itu kegiatan belajar harus dapat membekali peserta didik dengan kecakapan hidup (life skill atau life competency) yang sesuai dengan lingkungan kehidupan dan kebutuhan peserta didik. Pemecahan masalah secara reflektif sangat penting dalam kegiatan belajar yang dilakukan melalui kerjasama secara demokratis. Unesco (dalam Mulyasa, 2005) mengemukakan dua prinsip pendidikan yang sangat relevan dengan Pancasila. Pertama, pendidikan harus diletakkan pada empat pilar, yaitu belajar mengetahui (learning to know), belajar melakukan (learning to do), belajar hidup dalam kebersamaan (learning to life together), dan belajar menjadi diri sendiri (learning to be); kedua, belajar seumur hidup (life long learning). Kultur yang demikian harus dikembangkan dalam pembangunan manusia, karena pada akhirnya aspek kultural dari kehidupan manusia lebih penting dari pertumbuhan ekonomi.

Lebih lanjut, Mulyasa (2002) menyatakan tatanan kehidupan masyarakat yang semrawut (chaos) merupakan akibat dari sistem perekonomian yang tidak kuat, telah 
mengantarkan masyarakat bangsa pada krisis yang berkepanjangan. Krisis yang terjadi dalam berbagai bidang kehidupan sebenarnya bersumber dari rendahnya kualitas, kemampuan, dan semangat kerja. Secara jujur dapat kita katakan bahwa bangsa ini belum mampu mandiri dan terlalu banyak mengandalkan intervensi pihak asing. Meskipun agenda reformasi terus digulirkan untuk memperbaiki sendi-sendi kekuatan dengan menetapkan prioritas tertentu. Hal tersebut belum berlangsung secara kaffah (menyeluruh), baru pada tahap mencari siapa bersalah.

Peningkatan kualitas sumber daya manusia merupakan prasyarat mutlak untuk mencapai tujuan pembangunan. Salah satu wahana untuk meningkatkan kualitas SDM tersebut adalah pendidikan, sehingga kualitas pendidikan harus senantiasa ditingkatkan. Sebagai faktor penentu keberhasilan pembangunan, pada tempatnyalah kualitas SDM ditingkatkan melalui berbagai program pendidikan yang dilaksanakan secara sistematis dan terarah berdasarkan kepentingan yang mengacu pada kemajuan ilmu pengetahuan dan teknologi (Iptek) dan dilandasi oleh keimanan dan ketakwaan (Imtak).

Untuk mengantisipasi persoalan pendidikan yang dikemukakan oleh Tilaar, dan dalam rangka melaksanakan otonomi daerah, mengantisipasi perubahan-perubahan global pada persaingan pasar bebas, serta tuntutan kemajuan ilmu pengetahuan, dan teknologi, khususnya teknologi informasi yang makin hari makin canggih, maka pemerataan pelayanan pendidikan perlu diarahkan pada pendidikan yang transfaran, berkeadilan, dan demokratis (democratic education). Hal tersebut harus dikondisikan dalam lingkungan keluarga, sekolah, dan masyarakat. Dalam hal ini, sekolah sebagai sebuah masyarakat kecil (mini society) yang merupakan wahana pengembangan peserta didik, dituntut untuk menciptakan iklim pembelajaran yang demokratis (democratic instruction), agar terjadi proses belajar yang menyenangkan (joyfull learning) (Mulyasa, 2005).

Kurikulum merupakan rencana tertulis yang berisi tentang ide-ide dan gagasangagasan yang dirumuskan oleh pengembang kurikulum. Rencana tertulis itu kemudian menjadi dokumen kurikulum yang membentuk suatu sistem kurikulum yang terdiri dari komponen-komponen yang saling berkaitan dan saling memengaruhi satu sama lain, seperti misalnya komponen tujuan yang menjadi arah pendidikan, komponen pengalaman belajar, komponen strategi pencapaian tujuan, dan komponen evaluasi. Komponen-komponen yang membentuk sistem kurikulum selanjutnya melahirkan sistem pengajaran, dan sistem pengajaran itulah yang menjadi pedoman guru dalam pengelolaan proses belajar mengajar di dalam kelas. Dengan demikian maka dapat dikatakan sistem pengajaran merupakan pengembangan dari sistem kurikulum yang digunakan. Oleh karena sistem pengajaran melahirkan tindakan-tindakan guru dan siswa, maka dapat juga dikatakan bahwa tindakan-tindakan itu pada dasarnya implementasi dari kurikulum, yang selanjutnya implementasi itu akan memberikan masukan dalam proses perbaikan kurikulum. Demikian terus menerus, sehingga proses pengembangan kurikulum membentuk siklus yang tanpa ujung. 
Dari uraian di atas, maka jelas bahwa kurikulum dan pengajaran merupakan dua hal yang tidak terpisahkan walaupun keduanya memiliki posisi yang berbeda. Kurikulum berfungsi sebagai pedoman yang memberikan arah dan tujuan pendidikan, serta isi yang harus dipelajari. Sedangkan pengajaran adalah proses yang terjadi dalam interaksi belajar dan mengajar antara guru dan siswa. Posisi kurikulum dan pengajaran ini diungkapkan Saylor et al. (1981): 'The terms curriculum and instruction are interlocked almost as inextricable as name Tristan and Isoled or Romeo and Juliet. Without a curriculum or plan, there can be no effective instruction; and without instruction the curriculum has litle meaning.'

Bagi Saylor et al., kurikulum dan pengajaran itu seperti Romeo dan Juliet. Artinya, berbicara tentang Romeo adalah berbicara juga tentang Juliet. Romeo tidak akan berarti apaapa tanpa Juliet, dan juga sebaliknya. Tanpa kurikulum sebagai sebuah rencana, maka pembelajaran atau pengajaran tidak akan efektif, demikian juga tanpa pembelajaran atau pengajaran sebagai implementasi sebuah rencana, maka kurikulum tidak akan memiliki arti apa-apa.

Seperti yang diungkapkan Saylor et al. (1982), lebih lanjut Olivia (1992) menyatakan bahwa kurikulum dan pengajaran memiliki keterkaitan yang sangat erat. Kurikulum berhubungan dengan isi (materi) yang harus dipelajari sedangkan pengajaran berkaitan dengan cara mempelajarinya. '... curriculum as that which is taught and instruction as the means used to teach that which is taught. Even more simply, curriculum can be conceived as the 'what' and instruction as the 'how.' We may think of the curriculum as a program, a plan, content, and learning experiences, where as we may characterize istruction as method, the teaching act, implementation, and presentation.

Bagi Olivia, kurikulum berkaitan dengan apa yang harus diajarkan, sedangkan pengajaran mengacu pada bagaimana cara mengajarkannya. Dengan demikian, bagi Olivia kurikulum berhubungan dengan sebuah program, sebuah perencanaan, isi atau materi pelajaran serta pengalaman belajar. Sedangkan pengajaran berkaitan dengan metode, tindakan mengajar, implementasi, dan presentasi.

Dari uraian di atas, maka jelas ketika kita memikirkan apa yang harus dipelajari siswa, materi apa yang akan disampaikan, pengalaman belajar apa yang harus dimiliki siswa, maka pada saat itu kita sedang mengembangkan sebuah program, sebuah perencanaan atau sebuah kurikulum. Selanjutnya, manakala kita memikirkan bagaimana cara yang dapat dilakukan untuk mengajarkan suatu materi, metode apa yang harus digunakan, bagaimana menyusun implementasi program dalam tindakan nyata, maka pada saat itu kita sedang menyusun program pengajaran.

Selanjutnya, sistem pengembangan kurikulum akan melahirkan rangkaian pengajaran serta hasil yang diharapkan sesuai dengan kurikulum. Rangkaian pengajaran inilah yang kemudian akan mengkristal dalam sistem pengajaran yang tiada lain adalah tindak lanjut dari pengembangan sistem kurikulum. Dalam implementasinya sistem pengajaran akan dipengaruhi oleh isi pelajaran (keluasan dan kedalaman materi serta jenis materi pelajaran itu sendiri) dan berbagai instrumen pendukung yang kesemuanya itu tidak akan lepas dari sosial budaya masyarakat. Sistem pengajaran secara langsung dapat dipengaruhi oleh perilaku mengajar (seperti kualitas pengajaran, waktu pengajaran, kemampuan mengajar, guru, dan lain sebagainya). Dari sistem pengajaran itulah selanjutnya dapat melahirkan hasil belajar siswa.

Agar kurikulum itu bisa diturunkan menjadi program pengajaran dalam bentuk rencana pelaksanaan pembelajaran (RPP), maka kurikulum yang dikeluarkan oleh Kemendiknas harus dikonversikan dulu menjadi silabus. Menurut Anwar Us dan Harmi (2011), silabus adalah rencana pembelajaran pada suatu kelompok mata pelajaran dengan tema tertentu, yang mencakup standar kompetensi, kompetensi dasar, materi pembelajaran, indikator, penilaian, 
alokasi waktu, dan sumber belajar yang dikembangkan oleh setiap satuan pendidikan. Sedangkan Majid (2007), menyatakan istilah silabus juga dapat didefinisikan sebagai garis besar, ringkasan, ikhtisar atau pokok-pokok isi atau materi pembelajaran. Silabus digunakan untuk menyebutkan suatu produk pengembangan kurikulum berupa penjabaran lebih lanjut dari standar kompetensi dan kompetensi dasar yang ingin dicapai, dan menjelaskan tentang pokokpokok materi yang dipelajari siswa.

Silabus bermanfaat sebagai pedoman dalam pengembangan pembelajaran lebih lanjut, seperti pembuatan rencana pembelajaran, pengelolaan kegiatan pembelajaran, dan pengembangan sistem penilaian. Silabus merupakan sumber pokok dalam penyusunan rencana pembelajaran, baik rencana pembelajaran untuk satu standar kompetensi (SK) maupun satu kompetensi dasar (KD). Silabus juga bermanfaat sebagai pedoman untuk merencanakan pengelolaan kegiatan pembelajaran, misalnya kegiatan belajar secara klasikal, kelompok kecil, atau pembelajaran secara individual. Demikian pula, silabus sangat bermanfaat untuk mengembangkan sistem penilaian.

Berlandaskan Undang-Undang Republik Indonesia nomor 20 tahun 2003 tentang Sistem Pendidikan Nasional dan Peraturan Pemerintah (PP) nomor 19 tahun 2005 tentang Standar Nasional pendidikan (SNP), pemerintah melalui Departemen Pendidikan Nasional, berkewajiban menetapkan berbagai peraturan tentang standar penyelenggaraan pendidikan di seluruh wilayah Negara Kesatuan Republik Indonesia (NKRI). Standar nasional pendidikan yang dimaksud meliputi: (1) standar isi, (2) standar kompetensi lulusan, (3) standar proses, (4) standar pendidik dan tenaga kependidikan, (5) standar sarana dan prasarana, (6) standar pengelolaan, (7) standar pembiayaan, dan (8) standar penilaian pendidikan.

Salah satu dari kedelapan standar itu adalah standar isi. Standar isi memuat standar kompetensi (SK) dan kompetensi dasar (KD), yang harus dicapai siswa setelah mengikuti pembelajaran dalam jenjang dan waktu tertentu, sehingga pada gilirannya mencapai standar kompetensi lulusan (SKL). Agar peserta didik dapat mencapai SK, KD, maupun SKL secara optimal, perlu didukung oleh berbagai standar lainnya dalam sebuah sistem yang utuh. Salah satu standar tersebut adalah standar proses.

Standar proses mengisyaratkan bahwa guru diharapkan dapat mengembangkan perencanaan pembelajaran seperti rencana pelaksanaan pembelajaran (RPP), khususnya pada jenjang pendidikan dasar dan menengah. Rencana pelaksanaan pembelajaran (RPP) adalah rencana yang menggambarkan prosedur dan manajemen pembelajaran untuk mencapai satu atau lebih kompetensi dasar yang ditetapkan dalam standar isi dan dijabarkan dalam silabus (Mulyasa, 2006). RPP merupakan komponen penting dari KTSP, yang pengembangannya harus dilakukan secara profesional.

RPP dikembangkan berdasarkan karakteristik dan kondisi sekolah serta kemampuan guru dalam menjabarkan menjadi rencana pelaksanaan pembelajaran yang siap dijadikan pedoman pembentukan kompetensi peserta didik. Agar guru dapat membuat RPP yang efektif, dan berhasil guna, dituntut untuk memahami berbagai aspek yang berkaitan dengan hakikat, fungsi, prinsip, dan prosedur pengembangan, serta cara mengukur efektivitas pelaksanaannya dalam pembelajaran.

Rencana pelaksanaan pembelajaran (RPP) yang akan bermuara pada pelaksanaan pembelajaran, sedikitnya mencakup tiga kegiatan, yakni: (1) identifikasi kebutuhan, yang bertujuan untuk melibatkan dan memotivasi siswa, agar kegiatan belajar dirasakan oleh mereka sebagai bagian dari kehidupannya dan mereka merasa memilikinya, (2) identifikasi kompetensi yang harus dipelajari dan dimiliki siswa, perlu dinyatakan sedemikian rupa agar dapat dinilai sebagai wujud hasil belajar. Siswa perlu mengetahui tujuan belajar, dan tingkat-tingkat penguasaan yang akan digunakan sebagai kriteria pencapaian secara eksplisit, dikembangkan 
berdasarkan tujuan-tujuan yang telah ditetapkan. Oleh sebab itu, penilaian pencapaian kompetensi harus dilakukan secara objektif, berdasarkan kinerja siswa, dengan bukti penguasaan mereka terhadap suatu kompetensi yang telah ditentukan, dan (3) penyusunan program pembelajaran akan bermuara pada rencana pelaksanaan pembelajaran, sebagai produk program pembelajaran jangka pendek, yang mencakup komponen program kegiatan belajar dan proses pelaksanaan program. Komponen program mencakup kompetensi dasar, materi standar, metode dan teknik, media dan sumber belajar, waktu belajar, dan daya dukung lainnya (Mulyasa, 2006).

Dalam menurunkan silabus dari kurikulum yang sedang berlaku, sering sekali terjadi anomali konversi oleh kelompok kerja guru (KKG) yang sejenis. Anomalinya terjadi pada penyesuaian dengan kondisi sekolah di mana guru yang bersangkutan melaksanakan tugas. Ada beberapa kompetensi dasar (KD) yang susah dijangkau pada sekolah tempat kerja guru dihilangkan, sehingga isi atau materi ajar dari KD yang bersangkutan otomatis juga harus dihilangkan. Padahal materi ajar yang tercakup dalam KD yang dihapus tersebut sangat penting sekali untuk diajarkan atau diketahui oleh siswa. Saat pelaksaan Ujian Nasional (UN), karena kedudukan materi ajar yang dihilangkan itu penting dan mendasar diketahui oleh siswa harus muncul dalam tes hasil belajar bidang studi yang bersangkutan. Karena siswa memang sama sekali tidak pernah menyentuh materi ajar yang bersangkutan, maka siswa tidak bisa menjawab pada bagian materi ajar yang dihapus pada turunan kurikulum (silabus). Kejadian ini berujung pada hasil belajar yang relatif rendah pada bidang studi yang bersangkutan. Dan tudingan siswa yang mengatakan, tes UN yang sudah dikerjakan kebanyakan materinya susah-susah sekali dan beberapa soal sama sekali tidak pernah diajarkan di sekolah.

Tudingan siswa mengenai materi UN yang tertuang pada beberapa soal tes yang sama sekali tidak pernah diajarkan dan disentuh oleh guru bidang studi di sekolah, kemungkinan ada benarnya. Kebanyakan siswa yang menyampaikan tudingan seperti ini, dan memperoleh hasil belajar bidang studi yang bersangkutan yang relatif rendah disebabkan oleh guru di dalam menyusun program pembelajarannya, yakni dalam bentuk rencana pelaksanaan pembelajaran (RPP) mengikuti kurikulum aktual. Jawaban ini merupakan salah satu yang penulis kaji berbasiskan atas standar isi dalam program pembelajaran.

Sebagai suatu rencana atau program tertulis, kurikulum merupakan pedoman bagi guru dalam melaksanakan kegiatan belajar mengajar di sekolah. Oleh sebab itu, setiap guru seharusnya dapat melaksanakan kegiatan sesuai dengan tuntutan kurikulum. Inilah yang dinamakan kurikulum ideal, yaitu kurikulum yang diharapkan dapat dilaksanakan dan berfungsi sebagai acuan atau pedoman guru dalam proses belajar dan mengajar. Oleh karena kurikulum ideal merupakan pedoman bagi guru, maka kurikulum ini juga dinamakan kurikulum formal atau kurikulum tertulis (writen curriculum). Contoh dari kurikulum ini adalah kurikulum sebagai suatu dokumen seperti kurikulum SMU 1989, kurikulum SD 1975 yang berlaku pada tahun itu, dan lain sebagainya.

Sanjaya (2013) menyatakan, kurikulum ideal memegang peran yang sangat penting dalam merancang pembelajaran yang dapat dilakukan oleh guru dan siswa. Sebab, melalui pedoman tersebut guru minimal dapat menentukan hal-hal sebagai berikut. (1) Merumuskan tujuan dan kompetensi yang harus dimiliki oleh siswa. Dapat kita bayangkan tanpa tujuan yang jelas sebagai rambu-rambu, maka guru akan kesulitan menentukan dan merencanakan program pembelajaran, (2) menentukan isi atau materi pelajaran yang harus dikuasai untuk mencapai tujuan atau penguasaan kompetensi, (3) menyusun strategi pembelajaran untuk guru dan siswa sebagai upaya pencapaian tujuan, dan (4) menentukan keberhasilan pencapaian tujuan atau kompetensi. 
Apakah setiap kurikulum ideal dapat dilaksanakan sepenuhnya oleh guru? Tentunya tidak. Setiap sekolah tidak mungkin dapat melaksanakannya dengan sempurna, karena berbagai alasan. Pertama, bisa atau tidaknya kurikulum ideal diterapkan oleh guru, dapat ditentukan oleh kelengkapan sarana dan prasarana yang tersedia di sekolah. Misalnya, sekolah tidak punya peralatan untuk memperagakan mengenai cara presentasi menggunakan media komputer dan LCD, maka tuntutan kurikulum agar siswa mampu presentasi menggunakan komputer dan LCD tidak mungkin bisa dilaksanakan; kedua, bisa atau tidaknya kurikulum ideal dilaksanakan, akan ditentukan oleh kemampuan guru. Misalnya, sekolah memiliki peralatan mikroskop yang lengkap, namun guru-guru tidak ada yang bisa mengoperasikan mikroskop, maka tuntutan kurikulum mengenai kemampuan siswa untuk menggunakan mikroskop secara individu tidak mungkin bisa dilaksanakan; dan ketiga, bisa tidaknya kurikulum ideal dilaksanakan oleh setiap guru, juga tergantung pada kebijakan sekolah yang bersangkutan. Misalnya, di sekolah tersedia sarana belajar dengan lengkap sesuai dengan tuntutan kurikulum, demikian juga halnya dengan kemampuan guru, tetapi dengan alasan bahwa sarana atau alat tersebut merupakan alat yang mahal dan langka misalnya, maka kepala sekolah mengambil kebijakan alat tersebut tidak boleh digunakan, maka tidak mungkin kurikulum dapat dilaksanakan dengan optimal.

Ketiga hal tersebut, merupakan faktor yang dapat atau tidaknya kurikulum ideal dilaksanakan oleh setiap guru. Oleh karena berbagai keterbatasan itu, maka guru hanya mungkin dapat menerapkan kurikulum sesuai dengan kondisi yang ada. Inilah yang kemudian dinamakan kurikulum aktual (actual curriculum), atau kurikulum nyata, yakni kurikulum yang secara riil dapat dilaksanakan oleh guru sesuai dengan keadaan dan kondisi yang ada.

Oleh karena kurikulum ideal merupakan pedoman bagi setiap guru khususnya tentang tujuan dan kompetensi yang harus dicapai, sedangkan kurikulum aktual merupakan kurikulum nyata yang dapat dilaksanakan oleh guru sesuai dengan kondisi yang ada, dengan demikian dapat dipastikan bahwa makin jauh jarak antara kurikulum ideal dengan kurikulum aktual, artinya apa yang dikerjakan guru tidak sesuai atau jauh dari rambu-rambu kurikulum ideal maka makin rendah kualitas suatu sekolah. Sebaliknya, makin dekat jarak antara kurikulum ideal dengan kurikulum aktual, artinya apa yang dilakukan guru dan siswa sesuai dengan ramburambu bahkan melebihi kurikulum ideal sebagai pedoman, maka akan makin bagus kualitas suatu sekolah atau kualitas proses belajar mengajar.

Indikator dari kualitas sekolah yang tinggi adalah hasil belajar yang dicapai siswa sesuai dengan atau melebihi dari standar kompetensi lulusan (SKL), yang dicerminkan dalam kriteria ketuntasan minimal (KKM) pada suatu bidang studi. Dari sini dapat dikatakan bahwa makin jauh kesenjangan antara kurikulum aktual dengan kurikulum ideal, dapat menyebabkan hasil belajar siswa pada suatu bidang studi kebanyakan berada di bawah KKM, yang berarti kualitas suatu sekolah dikatakan rendah. Sebaliknya, makin dekat kesenjangan atau bahkan tidak ada kesenjangan antara kurikulum aktual dengan kurikulum ideal, dapat menyebabkan hasil belajar siswa pada suatu bidang studi kebanyakan berada bahkan di atas KKM, yang berarti kualitas suatu sekolah dikatakan tinggi.

Bila kurikulum aktual menyentuh atau melebihi dari kurikulum ideal, maka hasil belajar siswa pada suatu bidang studi akan meningkat. Peningkatan hasil belajar pada suatu bidang studi, merupakan indikator dari kualitas sekolah yang tinggi. Sebaliknya, kurikulum ideal yang tidak pernah menyentuh, bahkan melenceng dari kurikulum ideal menyebabkan hasil belajar siswa pada suatu bidang studi akan rendah. Efek lanjutan dari hasil belajar siswa yang rendah, merupakan cerminan dari kualitas sekolah yang rendah 


\section{SIMPULAN}

\section{Simpulan}

Dalam mengonversikan kurikulum menjadi program pembelajaran dalam bentuk RPP pada suatu sekolah, seorang guru tidak boleh percaya langsung dengan silabus yang sudah dibuat oleh kelompok kerja guru (KKG) bidang studi yang sejenis. Seorang guru harus memeriksa silabus yang dibuat oleh KKG dengan sumbernya, yaitu kurikulum ideal. Makin jauh kesenjangan yang terjadi antara kurikulum ideal dengan kurikulum aktual, maka program pembelajaran yang dikomunikasikan oleh guru yang bersangkutan menyebabkan hasil belajar siswa menjadi rendah, yang berefek lanjut pada kualitas sekolah yang rendah. Sebaliknya, makin sempit, bahkan tidak ada kesenjangan antara kurikulum ideal dengan kurikulum aktual, maka program pembelajaran yang dikomunikasikan oleh guru yang bersangkutan menyebabkan hasil belajar siswa menjadi tinggi, yang berefek lanjut pada kualitas sekolah yang tinggi.

\section{DAFTAR PUSTAKA}

Anwar Us, Kasful dan Hendra Harmi. 2011. Perencanaan Sistem Pembelajaran Kurikulum Tingkat Satuan Pendidikan (KTSP). Bandung: Alfabeta.

Djamarah, Syaiful Bahri. 1994. Prestasi Belajar dan Kompetensi Guru. Surabaya: Usaha Nasional.

Hasibuan, J.J. dan A. Moerdjiono. 1986. Proses Belajar Mengajar. Bandung: PT Remajakarya.

Madjid, Abdul. 2007. Pendidikan Agama Islam Berbasis Kompetensi: Konsep dan Implementasi Kurikulum 2004. Bandung: PT Remaja Rosdakarya.

Mulyasa, E. 2002. Manajemen Berbasis Sekolah: Konsep, Karakteristik, dan Implementasi. Bandung: PT Remaja Rosdakarya.

2005. Kurikulum Berbasis Kompetensi: Konsep, Karakteristik, dan Implementasi. Bandung: PT Remaja Rosdakarya.

------. 2006. Kurikulum yang Disempurnakan: Pengembangan Standar Kompetensi dan Kompetensi Dasar. Bandung: PT Remaja Rosdakarya.

Nurhadi. 2004. Kurikulum 2004: Pertanyaan dan Jawaban. Bandung: Grasindo.

Olivia, Peter F. 1988. Developing Curriculum: A Guide to Problems, Principles and Process. New York: Harper \& Publisher.

Peraturan Pemerintah Nomor 19 Tahun 2005 tentang Standar Nasional Pendidikan. Jakarta: Kemendiknas. 
Puger, I Gusti Ngurah. 2016. "Konstruksi dan Analisis Hasil Uji-Coba Tes Hasil Belajar Biologi." Laporan Karya Inovatif Universitas Panji Sakti Tahun 2016.

Redana, Dewa Nyoman. 2017. "Hasil Belajar Sebagai Alat Motivasi Belajar Mahasiswa." Dalam Prosiding Seminar Revitalisasi Tata Kelola Perguruan Tinggi. Singaraja: P3M Unipas.

Sanjaya, Wina. 2010. Strategi Pembelajaran Berorientasi Standar Proses Pendidikan. Jakarta: Kencana Prenada Media Group.

------. 2013. Kurikulum Pembelajaran. Jakarta: Kencana Prenada Media Group.

Saylor, J. Galen et al. 1981. Curriculum Planning for Better Teaching and Learning. USA: HoltReinhart and Winston.

Soetomo. 1993. Dasar-Dasar Interaksi Belajar Mengajar. Surabaya: Usaha Nasional.

Tilaar, H.A.R. 1994. Manajemen Pendidikan Nasional: Kajian Pendidikan Masa Depan. Bandung: PT Remaja Rosdakarya.

Undang-Undang Nomor 20 Tahun 2003 tentang Sistem Pendidikan Nasional. Jakarta: Kemendiknas. 